\title{
The Strategy of Improving Principal's Managerial Performance through the Adaptability of New Technologies
}

\author{
S T Satyawati ${ }^{1}$, R E Siswoyo ${ }^{2}$, S. Martono ${ }^{3}$, Achmad Rifai ${ }^{4}$ \\ ${ }^{1}$ Educational Management Graduate School, Universitas Negeri Semarang, Semarang, Indonesia \\ 2,3,4 Educational Management Graduate School, Universitas Negeri Semarang, Indonesia \\ ${ }^{1}$ Corresponding email: sophieschoise@yahoo.co.id
}

\begin{abstract}
The principals main task is as a manager and in line with the development of the technology, the principal as an agent of change must be able to adapt to implement new technology in managing schools. The objective of this study is to reveal the influence of adaptability of new technology implementation toward the improvement of principals managerial performance. The method used in this study was by using quantitative methods. The population in this research was elementary school principal in Semarang regency of 510. The sample in this research was determined based on Cluster Sampling technique of 127 people. The data were collected through questionnaires that have been tested for their validity and reliability. The technique of data analysis wasby using path analysis with SPSS 21 software. The result of research shows that the improvement of managerial performance of elementary school principals in Semarang Regency is influenced by the adaptability of principals. The suggestions from the results of this study principals as agents of change in the $21^{\text {st }}$ century, they need to adjust to improve the ability to implement new technological changes to improve managerial performance.
\end{abstract}

Keywords: Adaptability, Principals Managerial Performance

\section{Introduction}

The principal's main task is as a manager and in line with the development of the technology, the principal as an agent of change must be able to adapt to implement new technology in managing the school. The measurement of school principals' achievement is based on the fulfillment of educator standards and education personnel as mandated in the Government Regulation No. 19/2005 on National Education Standards. The regulation is both a reference and a criterion for improving and ensuring the quality of education.

A good performance is one of the goals of the organization in achieving high work productivity. A performance is an achievement or level of success achieved by a person or an organization in carrying out work in a certain period (Robbins, 2007). In line with those definitions, the performance of the principal is the work achieved by the principal in carrying out his/her main tasks, the functions and responsibilities in managing the school he.she leads (Department of National Education, 2008: 4). The work is a reflection of the competence he/she has. While the principal main task is managing and providing educational services for all learners in schools to achieve quality education.
The Regulation of Minister of National Education No. 13 of 2007 on Principal/ Madrasah Standards mandates, that to be able to carry out his/her role and his/her function as the manager, a principal is required to have managerial competence covering 3 (three) components: (1) planning; (2) manage resources consisting of managing change, human resources, and other resources; (3) evaluate and follow up. These competencies should ideally be met by the principal and actualized in everyday activities, thus demonstrating high managerial performance. But the phenomenon that occurs in the field, indicates the managerial competence of the principal has not been optimal, so the managerial performance of the principal is still low.

Other facts indicate that the results of the principal's performance assessment through the latest online Principal Competency Test (PCT) conducted by the Center for the Empowerment of Professional Personnel of Agency for Development Human Resources Education of Ministry of Education and Cultural in 2015 shows the national average is low, because it has not reached the Minimum Mastery Standard set, 70 (from a scale of 0 100). The average value of the national online PCT is 44.24 and the average grade for the lowest grade of PCT is 42.60 . The number of 
school principals/ madrasah tested are 208,000 people.

The average score of national PCT per dimension, indicating the managerial dimension of 47.11 , it is still far below the Minimum Mastery Standard (70). This means that the managerial competence of principals in Indonesia is still very low, whereas managerial competence is the principal's power to manage the school well (Dharma, 2009). Low managerial competence reflects low managerial performance. The phenomenon occurring in some elementary schools in Semarang Regency shows that the low managerial performance is influenced by the adaptability behavior of the principal that has not been optimal yet.

One of the behaviors that humankind needs in the 21 st century to deal with rapid changes is adaptability, that is, the ability to adapt and adopt with changes that occur in line with the dynamics of life (Slameto, 2018: 2). One of the major important changes immediately responded and adopted in the last few decades, is the advancement of Information and Communication Technology (ICT), which is supported by the use of computers in education. The schools with high adaptability are schools that are responsive to such changes. Khotimah (2017) states that adaptation is a very important aspect that must be owned by employees and also a determinant factor of employee success in carrying out his work in everyday life. This is supported by the opinion of Walker \& Boyne (2006), that the success of an organization depends on internal adaptation to the environment. Aragon (2007) explains that adaptability has a positive and significant influence on organizational performance.

The research's results of Locander \& Jaramillo (2006); Burpitt, William, J (2008); shows that the ability to adapt to the environment positively and significantly affects the company's performance. In the educational organization, it is revealed that the principals who receive the resilience model, they reflect the adaptation of major changes, a tough principal is able to adapt to change successfully not only improve their school performance but also become effective leaders. To face the change, the principal must be sensitive to external realities in a global environment (Isaacs, 2016). In contrast to this studies, Muhtaram, A., Chusnul, T., \& Rosalin,
E (2009) suggest that organizational adaptability has no direct effect on organizational performance in the universities.

In line with the adaptability of new technological changes, the research of Destiana, B. (2014) reveals that the use of ICT influences the performance of teachers. Similarly, Safelia, N, Susfayetti \& Friyani, R (2012) study reveals that the new information technology improve the performance of individuals in the company/ organization, it shows a positive and significant influence. Pfano, M., \& Beharry, A. (2016) state the strong correlations between the use of appropriate office technology and positive change in management performance. In contrast to the research of Wijayanti, W.S. (2017) the utilization of good information technology has not been able to improve employee's performance.

\section{Method}

The population that became the object in this study was the principal at Elementary School level in Semarang regency as many as 510 people. The sample in this research was determined based on Cluster Sampling technique (Area Sampling). Researchers took samples of $25 \%$ x $510=127$ people.

The variables that will be analyzed in this research were: (1) Adaptability was selfassessment of respondent towards the condition that can show responsive and proactive attitude of school principal in adjusting to internal and external factors of organization, it includes dimension of: Creating Change, Costumer Focus, and Organizational Learning (Denison dan Mirsha (1995). (2) Principal's Managerial Performance is the respondent's selfassessment of a condition that can indicate the principal's ability to perform the main tasks as manager, including the dimensions of : planning, management, evaluation, and followup (The Regulation of Minister of National Education No. 13 of 2007). Each question item was measured by using seven measurement scales, where 1 indicates "very rarely done" and 7 indicates "always done".

The study used two data analyzes. First, descriptive analysis was conducted in this research to describe the answers and responses of respondents about the behavior of adaptability and principal's managerial performance. Second, statistical analysis to 
answer the research problem, and the hypothesis testing was conducted by analyzing and testing the empirical model. Hypothesis model testing was by using path analysis with SPSS 21 software.

The framework of causality relationship between variables proposed in this study is:

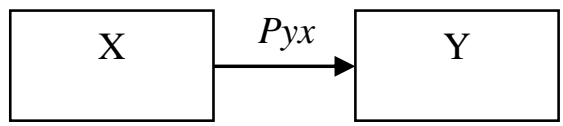

Figure 2. Causality Relationships between Variables

Its classification:

1) Independent Variable: Adaptability (X)

2) Dependent Variables: Principal's Managerial Performance (Y)

\section{Results dan Discussion}

The description of data on the variable adaptability of new technology is shown by the table as follows.

Table 1. The Description Data of Adaptability Variable

\begin{tabular}{clcl}
\hline $\begin{array}{c}\text { Interv } \\
\text { al } \\
\text { Score }\end{array}$ & $\begin{array}{c}\text { Categor } \\
\text { y }\end{array}$ & $\begin{array}{c}\text { Frequen } \\
\text { cy }\end{array}$ & $\begin{array}{c}\text { Percenta } \\
\text { ge } \\
(100 \%)\end{array}$ \\
\hline $\begin{array}{c}69- \\
76\end{array}$ & $\begin{array}{l}\text { Very } \\
\text { high }\end{array}$ & 12 & 9.45 \\
$63-$ & High & & \\
68 & & 36 & 28.35 \\
$57-$ & Sufficie & & \\
62 & nt & 41 & 32.28 \\
$51-$ & Low & & \\
56 & & 26 & 20.47 \\
$44-$ & Very & & \\
50 & low & 12 & 9.45 \\
& & & \\
Total & & 127 & 100.00 \\
\hline
\end{tabular}

Table 1. above shows the perception of respondents to the Adaptability variable, there are 12 respondents $(9.45 \%)$ included in the very high category, there are 36 respondents $(28.35 \%)$ which belongs to high category, there are 41 respondents $(32.28 \%)$ on sufficient category, there are 26 respondents $(20.47 \%)$ which belong to low category, and there are 12 respondents $(9.45 \%)$ which belong to very low category. Thus the ability to principal's adaptability in implementing new technology according to the perception of respondents in general are included in the sufficient category.

The description data on principal's managerial performance variable is presented in the following table 2 .

Table 2. The Description Data of Principal's Managerial Performance Variable

\begin{tabular}{clcc}
\hline $\begin{array}{c}\text { Interval } \\
\text { Score }\end{array}$ & Category & Frequency & $\begin{array}{c}\text { Percentage } \\
(100 \%)\end{array}$ \\
\hline $\begin{array}{c}128- \\
136\end{array}$ & Very & & \\
$119-$ & High & 25 & 19.69 \\
127 & High & 29 & 22.83 \\
$110-$ & & & \\
118 & Sufficient & 28 & 22.05 \\
$101-$ & & & \\
109 & Low & 31 & 24.41 \\
$92-$ & Very & & \\
100 & Low & 14 & 11.02 \\
& & & \\
Total & & 127 & 100.00 \\
\hline
\end{tabular}

Table 2. above shows the principal managerial performance variable according to the respondent's perception that there are 25 respondents $(19.69 \%)$ which is included in very high category, there are 29 respondents $(22.83 \%)$, which is included in high category, there are 28 respondents $(22.05 \%)$ are included in the sufficient category, there are 31 respondents $(24.41 \%)$ are included in the low category, and there are 14 respondents $(11.02 \%)$ are included in the very low category. Thus, the managerial performance according to the respondent's perception is generally included in the low category.

The assumptions test in parametric analysis include: normality test, linearity test, and multicolonierity test by using SPSS 21 application program that is shown in the following table.

Table 3. Assumption Test Results of Adaptability and Principal Managerial Performance Variables

\begin{tabular}{ccccc}
\hline \multicolumn{2}{c}{$\begin{array}{c}\text { Normality } \\
\text { Test } \\
\text { (Kolmogoro } \\
\text { v-Smirnov) }\end{array}$} & $\begin{array}{c}\text { Lineari } \\
\text { ty Test }\end{array}$ & \multicolumn{2}{c}{$\begin{array}{c}\text { Multicolonierit } \\
\text { y Test }\end{array}$} \\
\cline { 3 - 5 } & & & \\
$\mathrm{X}$ & $\mathrm{Y}$ & $\mathrm{X}-\mathrm{Y}$ & \multicolumn{2}{c}{$\mathrm{X}-\mathrm{Y}$} \\
\cline { 4 - 5 } & & & $\begin{array}{c}\text { Toleran } \\
\text { ce }\end{array}$ & VIF \\
0.08 & 0.15 & 0.86 & 0.543 & $\begin{array}{c}1.84 \\
3\end{array}$ \\
& 6 & & & 2 \\
\hline
\end{tabular}


Table 3. Normality test by using Kolmogorov-Smirnov criteria shows significant value ( $p$ value) of all variables above $>0.05$, then all data variables are normally distributed. The linearity test in this study indicates that all variables obtain significance value higher than 0.05 , it means that there is a significant linear relationship between variables. Tolerance values for all variables show higher than 0.10 and VIF values lower than 10.00 . This means there is no multicolonierity.

The results of the dependent regression analysis of principal managerial performance variables are shown in Table 4. below.

Table 4. Regression Analysis of Dependent Variables of Principal's Managerial Performance (Y)

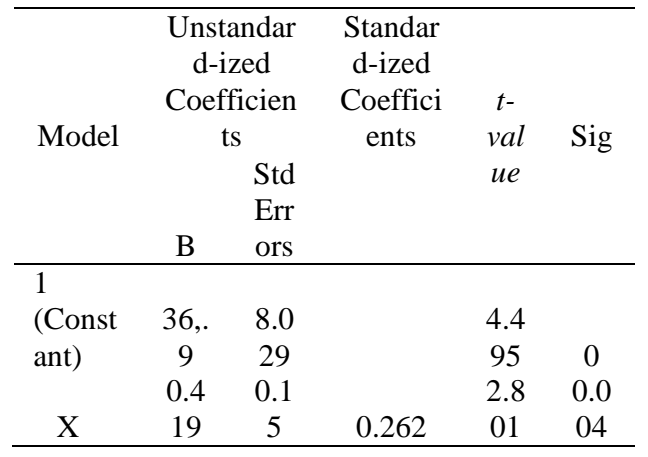

The hypothesis proposed in this research is the adaptability has a positive and significant influence on the principal's managerial performance. Based on the empirical analysis in Table 4. The value of regression coefficient of adaptability (X) effect on principal managerial performance $(\mathrm{Y})$ is 0.262 or equal to $(0.262)=0.0686$ or $6.86 \%$ and this coefficient is positive. This shows that if adaptability is improved or better then the principal's managerial performance will increase as well. The model of adaptability relationship of new technology with principal's managerial performance is significant, it is indicated by the value of test $t$ $=2.801$ higher than $\mathrm{t}$ table alpha $0.05(\mathrm{df}=$ 127) equal to 1.656 . Thus the hypothesis of this research is supported, it means that the principal's managerial performance is influenced by the adaptability of new technology implementation. With the improvement of adaptability of new technology implementation, it will more improve the principal's managerial performance. This indicates that to improve the principal's managerial performance is built by the adaptability of principal of the new technology implementation.

The findings of this study support the theory presented by Khotimah (2007), and Widoyoko (2012: 213) that employee's adaptability influences organizational performance. This is supported by the opinion of Walker \& Boyne (2006), that the success of an organization depends on internal adaptation to the environment. Aragon (2007) states that adaptability has a positive and significant impact on organizational performance.

The results of this study are supported by the research of Locander \& Jaramillo (2006); Burpitt, W.J (2008), that the ability of adaptation to the environment affects positively and significantly to company performance. The research of Yun Qui, \& Tannock, (2010), shows that to build the quality, it is required ability/attitude to adapt towards change. Isaacs' research (2016), reveals that to face change, the principal should be sensitive to external realities in a global environment.

\section{Conclusion}

Based on the findings of this study, the implications of managerial on educationla units are as follows, the effort to improve the principal"s managerial performance can be achieved by improving the adaptability of new principal techology implementation. Because in this research proves that ability of adaptability of new technology implementation able to improve principal's managerial performance.

\section{References}

Aragon-Correa, J. A., Garcia-Morales, V. J \& Cordon - Pozo, E. 2007. Leadership and Organizational Learning's Role on Innovation and Performance: Lessons from Spain. Industrial Marketing Management. 36 (3): 349359

Burpitt, W. Jr. 2010. "Balancing Exploration and Exploitation in a Declining Industry: Antecedents To Firm Adaptation Strategy And Performance". Journal of Small Business Strategy, Vol. 21, No.1

Denison, D.R, \& Mishra, A.K. 1995. Toward a theory oforganizational culture and 
effectiveness. JSTOR. INFORM: Organizationalscience Vol 6 No.2

Dharma, S. 2002. Paradigma Baru: Manajemen Sumber Daya Manusia. Yogyakarta: Amara Books.

Isaacs, A.J. 2016. "Resiliency and the Individual Demographics of School Leaders: Making a Difference in the Quality of Educational Leadership". Journal University of North Florida. Vol. 3, Issue 3.

Khotimah, S. K. 2007. "Hubungan antara penyesuaian diri dalam kelompok kerja dengan semangat kerja karyawan dinas kesehatan kota di jalan pandaran Semarang".Unpublished undergraduate thesis, Universitas Negeri Semarang, Semarang

Locander, M. \& Jaramillo, J. C.2006. On Strategic Net Works. Strategic Management Journal. 9: 31-41.

Muhtaram, A, Chusnul, T, Rosalin, E. 2009. "Peran Pimpinan dalam Learning Organization Adaptabilitas Organisasi dan Dampaknya Terhadap
Kinerja Organisasi Perguruan Tinggi”. Jurnal Laporan Penelitian. Bandung : Universitas Pendidikan Indonesia

Pusbangtendik BPSDMPK Kemendikbud .2015 . Uji Kompetensi Kepala Sekolah dan Pengawas Sekolah (UKPS)On-line file:///D:/Hasil\%20UKKS\%20UKPS\% 20tahun\%202015.pdf\%20\%20Google\%20Drive.htm. Accessed Desember 2, 2017

Robbins, S.P, \& Judge, T.A. 2007. Perilaku Organisasi. Jakarta: Salemba Empat.

Slameto. 2018. " Trend Pendidikan Abad ke 21 dan Implikasinya Bagi Pendidik di Indonesia”. Materi makalah seminar sehari tanggal 14 Mei 2018 Pascasarjana Manajemen pendidikan Universitas Kristen Satyawacana Salatiga.

Walker, R . M \& Boyne, G. A. 2006. "Strategy Content and Organizational Performance. An Empirical Analysis". Public Administration Review. 52-63. 